\title{
The altruistic homicides of Jean-Claude Romand: an autopsy of family secretes
}

\author{
Alexia Paraskevoulakou ${ }^{1 *}$, Vasiliki Antonopoulou² \\ From $1^{\text {st }}$ International Congress on Neurobiology and Clinical Psychopharmacology and European \\ Psychiatric Association Conference on Treatment Guidance \\ Thessaloniki, Greece. 19-22 November 2009
}

\section{Background}

The case of Romand concerns a man who pretended to be a medical doctor and killed his family while the fake identity he had cautiously impersonated for 18 years was about to be exposed. The purpose of this study is to determine the motive of Romand's following criminal act. In 1993, Romand smashed his wife's skull and shot his children while asleep. Afterwards, he joined his parents for a meal and shot them both. Later that night, he attacked his ex-mistress, but strangely enough, the few words she uttered, made him apologise and release her. He finally returned to his family home, which still contained the bodies of his dead wife and children, and set it on fire.

\section{Materials and methods}

After a bibliographic review of all reliable sources relative to this clinical case, we shall focus on the subversive events preceding the criminal act and examine three key aspects of Romand's life: 1) his enigmatic relationship with women, and especially with his wife and his mistress 2) the paternal role model he was for the local community, strongly suggesting that Romand assumed the exceptional role of a sacrificial figure 3 ) the criminal sequence.

\section{Results}

Romand's case extraordinarily contradicts the utilitarian motive allegation.

\section{Conclusions}

Romand's criminal gesture finds its own reason only if examined through the specificity of altruistic homicides. He tragically spared his family circle the shaking

${ }^{1}$ Department of Psychology, University of Paris VIII, Paris, France encounter with an intimate stranger who chose to invent the life he most certainly could have lived. This study represents a step toward understanding altruistic homicide risk.

\section{Author details}

'Department of Psychology, University of Paris VIII, Paris, France. ${ }^{2}$ Hospital of Paidon Agia Sophia, Athens, Greece.

Published: 22 April 2010

doi:10.1186/1744-859X-9-S1-S230

Cite this article as: Paraskevoulakou and Antonopoulou: The altruistic homicides of Jean-Claude Romand: an autopsy of family secretes. Annals of General Psychiatry 2010 9(Suppl 1):S230.
Submit your next manuscript to BioMed Central and take full advantage of:

- Convenient online submission

- Thorough peer review

- No space constraints or color figure charges

- Immediate publication on acceptance

- Inclusion in PubMed, CAS, Scopus and Google Scholar

- Research which is freely available for redistribution

Submit your manuscript at www.biomedcentral.com/submit
C Biomed Central 